Article

\title{
Linking the Local and the Global. What Today's Environmental Humanities Movement Can Learn from Their Predecessor's Successful Leadership of the 1965-1975 War to Save the Great Barrier Reef
}

\author{
Iain McCalman \\ Department of History, University of Sydney, Sydney NSW 2006, Australia; iain.mccalman@usyd.edu.au
}

Received: 30 August 2017; Accepted: 9 October 2017; Published: 16 October 2017

\begin{abstract}
For a decade from 1965-1975, an Australian poet, Judith Wright, and a Reef artist, John Busst, played a major role in helping to save the Great Barrier Reef. The Queensland State Government had declared its intention of mining up to eighty percent of the Reef's corals for oil, gas, fertiliser and cement. The campaign of resistance led by these two humanists, in alliance with a forester, Dr. Len Webb, contributed substantively to the establishment of the Great Barrier Reef Marine Park in 1975 and to then to the Reef's World Heritage listing in 1983 as 'the most impressive marine environment in the world'. This paper explains the challenges facing today's environmental scholars and activists as they attempt to replicate the success of their 1970s predecessors in helping to save the Great Barrier Reef from even graver and more immediate threats to its survival.
\end{abstract}

Keywords: environmental humanities; Great Barrier Reef; coal; mining; tourism

\section{Introduction}

Judith Wright, one of Australia's most beloved poets, was a foremost leader in a popular political war to save the Great Barrier Reef from destruction between 1963 and 1975, when the Queensland State Government launched a campaign to mine eighty percent of it for oil, gas, fertiliser, and cement, in conjunction with the deforestation of the Reef's adjacent rainforests to foster the sugarcane industry. Wright ended the twentieth anniversary edition of her famous book, Coral Battlefield (1996), with a new chapter called 'Finale without an Ending'. True, she and her colleagues had helped to save the Reef from this onslaught of threats to its survival by procuring for it Federal Government protection in 1975 as a National Marine Park and then World Heritage status in 1981. But popular memories could be short and fickle: renewed commercial attacks on the Reef could resume at any time (Wright 1996, pp. 195-96).

And so they have. But this time, the Reef faces still more urgent and lethal new menaces arising from a combination of coal mining and climate change. Environmental humanities defenders of the Great Barrier Reef are now engaged in a fresh war to prevent the total annihilation of 2300 kilometres of coral and, with it, the loss of one of the most beautiful natural sites on the globe, as well as the greatest hub and nursery of bio-diversity in the Indo-Pacific Oceans.

In this paper I want, first, to trace how a community coalition led by three remarkable individuals, Judith Wright, a poet; John Busst, an artist; and Len Webb, a forest scientist; came to lead and help win what I call the First Reef War of 1963-1975, and, secondly, to reflect on what lessons this previous victory holds for today's environmental humanities currently engaged in the second, and prospectively last possible Reef war. I argue that the key to the success of Wright, Busst, and Webb came from being a group of talented local Queensland community conservationists who forged a strategic and intellectual collaboration across the arts and sciences; and I suggest that environmental humanities advocates for 
the Reef today should attempt to do the same, notwithstanding the substantial differences between previous and current political circumstances that will undoubtedly complicate such efforts.

\section{Discussion}

In 1965, when the First Reef War began, Australian scientists knew remarkably little about the massive ecosystem along their eastern shore called the Great Barrier Reef, even though it encompassed an area of 350,000 square kilometres of coral reef, island, coast and lagoon-an area larger than Britain and Ireland put together. At this time, there were only three small, rudimentary marine research stations on the Reef, none of which contained full-time research scientists. Indeed, the first full-time Reef researcher, John Charlie Veron, was appointed to the sole local university in 1972, when the war was almost over. So when, like most wars, the Reef war started with a local skirmish, there were next to no trained professional soldiers ready to fight in its defence.

Midway through 1965, poet Judith Wright, the president of the small Brisbane-based community Wildlife Preservation Society of Queensland (WPSQ) that she'd founded in 1962, received a plea for help from John Busst, an artist who led a tiny local chapter of the WPSQ based at a small resort town in the central section of the Reef. The area was experiencing rapid deforestation to make way for sugar plantations, and John had learnt that a local sugarcane farmer had just made a formal application to the Queensland State government to mine what he called a 'dead' local reef for cheap limestone fertiliser. John immediately lodged an objection, which he supported with a barrage of letters to local newspapers, denying that Ellison Reef was 'dead'1 . Like all coral reefs, he argued, Ellison comprised corals living on the surface of vast limestone buttresses created from coral skeletons. He explained, too, that mining this reef would churn up clouds of asphyxiating silt, to be carried by waves and currents to kill other corals and seagrass habitats in a radius of at least one hundred kilometers. However, the Mining Warden's court refused to accept these arguments because Busst lacked scientific qualifications.

Squeaking an adjournment, John pleaded for help from scientists at the University of Queensland in Brisbane, the state's major university, only to encounter what would become a persistent problem (Clare 1971, pp. 94-97). Scientists were unwilling to testify because they, too, lacked qualifications in Reef coral biology and ecology. And Judith Wright's deputy, Len Webb, who at least had some scientific qualifications - albeit in forestry - happened to be overseas. Ever resourceful, Judith eventually found a handful of university zoology students from a community environmental group called the Queensland Littoral Society, who agreed to undertake an underwater survey of Ellison Reef, if John could fund them to get there (Webb 1967).

When the court resumed almost two years later, the student divers reported seeing 190 species of fish and 88 species of living coral on Ellison. Judith had also tracked down a qualified scientist to back them up: he was Dr. Don McMichael, a marine biologist working for the Australian Government in Canberra, and the Executive Director of the Australian Conservation Foundation, an elite and generally conservative new organisation founded to provide 'non-political' conservation advice to the Federal Government. Luckily, McMichael had done some work on Ellison many years earlier and found a rare species of mollusc there. Although permission to mine Ellison had been regarded as so much a foregone conclusion that a huge chunk of coral had already been gouged from the Reef, the Warden was forced to recommend against its further destruction.

This small local community victory unleashed a full-scale war over the Reef because it goaded the Queensland State Government into larger action. The Country Party, with the support of the minority Liberal Party, had already been in power in Queensland for a decade under the banner of 'Develop the North' and had come in the early 1960s to believe that the discovery of oil would prove to be the state's Nirvana. Without any constitutional authority, the Government also claimed absolute sovereignty

1 John Busst to Judith Wright, 2 September 1967, John Busst Collection, [JBC] James Cook University, JBC/Corr/13. 
over the Reef and it had, from 1963, secretly issued six licenses to global oil corporations to undertake test drilling on various parts of the Reef and the Torres Straits (Bowen and Bowen 2002, pp. 317-21).

In 1967 the oil companies found their messiah when a crafty Queensland nationalist and champion of unbridled development, Joh Bjelke-Petersen, succeeded to the position of Premier of Queensland. He and his Ministers immediately made large personal investments in the oil companies and proceeded to zone eighty percent of the Reef for oil and gas exploration. Bjelke-Peterson taunted Judith Wright and her WPSQ associates as 'flower-sniffing fools', 'nitwits', 'cranks', 'rat-bags', and 'commies' intent on overthrowing the Australian way of life (See Bowen and Bowen 2002, pp. 318-21; Lines 2006, pp. 146-47; Brady 1998, pp. 242-44, 255-59).

In May 1968 the Government also decided to justify its intention to mine the Reef for oil and gas by appointing Dr. Harry Ladd, an American geologist with extensive mining connections, to report on the Reef's commercial potential. Ladd spent a week flying over 2300 kilometres of coral in the company of the Government's mining officials and then filed a report in March 1968 that described the likelihood of gas and oil discoveries as 'promising'. He also recommended that 'non-living' reefs be used for fertiliser and cement manufacture (Clare 1971, pp. 114-15). A furious Judith Wright compared this to demolishing the Taj Mahal for road gravel. But what could a small group of local community conservationist led by a poet, a forester, and an artist do to halt Bjelke-Petersen's juggernaut of State politicians, corporate lawyers, local developers, and international mining corporations?

Judith Wright, born in 1915, had grown up in what she called 'my blood's country', the lean dry highlands area of New England in New South Wales around her family's pastoral station. Blessed with a soaring imagination, she became a Romantic poet in the deepest sense, using the power of language and symbol to express the harsh beauty of the Australian continent and the complex spiritual culture of its ancient Aboriginal custodians based on the spiritual and ecological ethic of 'caring for country (Brady 1998, pp. 112-13, 191)'. Living in a timber-cutter's cottage among the rainforests of Mount Tambourine in Queensland, Judith and her husband, Jack McKinney, a drover-turned-philosopher, developed a powerful critique of Australia's settler colonists who had stolen the lands of the Indigenous Australian peoples and created instead a society dedicated to material greed and exploitation.

The Barrier Reef's wonders and fragility had lodged deep in Judith's imagination in 1949, when she'd spent time on Lady Elliot Island on its southern boundary. She was shocked to see the ravages of guano mining for fertiliser, but fell in love with the beauty of the island's fringing coral reefs. These became her metaphor to describe lone individuals who, like tiny polyps, had the courage to build buttresses of moral resistance against oceanic forces of destruction. She called such brave resisters 'Builders', in a famous poem of that title:

Only those coral insects live

that work and endure under

the breakers' cold continual thunder.

They are the quick of the reef

that rots and crumbles in calmer water.

Only those men survive

who dare to hold their love against the world;

who dare to live and doubt what they are told.

They are the quick of life;

their faith is insolence; joyful is their grief (Wright 1994a, p. 45). 
Soon after she set up the Queensland Wildlife Society in Brisbane to educate children in conservationist principles and campaign against deforestation by developers, a local Brisbane forester, Dr. Len Webb, had asked to join. She instantly recognised him as a 'Builder'. The son of a sheep station cook mother and a horse-breaker father, he'd gained his scientific education at night school, which led to a wartime job in a munitions factory. The army then funded him to study biochemistry, before he received a life-changing job offer from an Australian Government science institute, the Commonwealth Scientific and Industrial Research Organisation (CSIRO) to help the war effort by surveying rainforests for medically useful plants.

With so many plants to study, he learnt to test for alkaloids on his tongue, using the folk knowledge of Aborigines, timber workers and tin scrapers (Tracey 1988). He also found that many of these loners shared his passion for 'the mystery and sacred beauty of the rain forests'. Len recalled one day experiencing an eerie epiphany: 'I was ... overwhelmed, without feeling claustrophobic or afraid, by this complex terrestrial ecosystem'. It was like being infused, he said, with 'soul', 'heart', or 'spirit' (Frazer 2003, pp. 163-64). He'd woken up an opponent of the status quo, determined to defend these wondrous forests that dated back to the days of Gondwanaland from predatory deforestation. After undertaking one of Australia's first ever PhDs in the new subject of ecology, he and an assistant were employed by the CSIRO to undertake an ambitious ecological mapping of all Australia's mainland rainforests.

John Busst, then an artist living on a Reef island, had met Len after sending him a local plant with medicinal properties. They became instant and lifelong friends, discovering a common love of scientific romanticism, Tennyson's poetry, Wagner's music, and the euphoric properties of rum². Yet their backgrounds and training could hardly have been more different. John, born into a wealthy Bendigo mining family, had studied law at the University of Melbourne, his best friend, Harold Holt, who in 1966 became Australia's Liberal Party Prime Minister. John, by contrast, had dropped out in the early 1930s to join an arts-and-crafts colony outside Melbourne, where he became a painter and a craftsman in adobe, wood, glass and stone (Roland 1984, pp. 14, 30, 44, 172-73). In 1940, a family bequest enabled him and his wife Alison to buy land on Bedarra Island in the Great Barrier Reef. Here they lived an alternative life for seventeen years, building a mud-brick house, laying out a tropical garden, selling the odd painting, and developing a passion for local birdlife.

In the mid-1950s, resort development on the island drove the Bussts to move to the opposite mainland coast at Bingil Bay. But on the evening they moved into their new hand-built, cyclone-proof, bungalow, they learned that an area of rainforest behind their garden had been co-opted by the army for exercises in defoliant bombing with Agent Orange (Clare 1971, pp. 88-92). Len Webb happened to be staying that night and volunteered at once to teach them ecological principles for fighting the proposal. Fired with a new ecological passion, John followed this success by pressing for protection throughout the larger Innisfail-Tully region of the rain forest, river and reef habitats that were under threat from cane farmers and army bombers.

This trio of Wright, Busst and Webb exchanged ideas and tactics so eagerly that they became, Judith said, 'welded in a very deep companionship' that was as much intellectual as personal. In order to convey the enormity of the threats to the Reef posed by oil mining and deforestation, they taught each other to understand, respect, integrate and convey the potency of their combined knowledges. For the next decade they disseminated a series of accessible books, articles, lectures, letters and talks. These espoused the principles of holism and interconnectivity offered by the new discipline of ecology in order to move people's minds, and the power of language, aesthetics, art and 'emotional intelligence' in order to move their hearts (Wildlife Preservation Society of Queensland 2000, p. 2).

Len's popular ecological writings thus stressed that humans must interact emotionally as well as rationally to non-human fauna and flora like fish, turtles and trees. Drawing on one of Judith's

2 (Frazer 2003, pp. 163); see also Busst's retrospective reflections in John Busst to Len Webb, 22 July 1968, JBC/Corr/6. 
poems, he argued that 'we need a new word to convey that feeling of deep enjoyment and wonder, that feeling of privilege in witnessing the life of wild animals and birds, and in moving amongst wild scenery'. But fighting such a formidable coalition of politicians and oil conglomerates was not easy. Judith's poem 'Australia 1970', came close to despair under the cumulative weight of their task:

For we are conquerors and self-poisoners

more than scorpion or snake

and dying of the venoms that we make

even while you die of us (Wright 1994b).

'If the Barrier Reef could think it would fear us', she fretted, ' . . we have its fate in our hands'. Oil and gas mining would deliver the killer blow to a Reef already dying from fertilisers, pesticides, dredging, sugar-plant effluent and urban sewage (Brady 1998, pp. 112-13, 191). And alongside her searing poems, she wrote influential articles like 'Conservation as a Concept', which hailed the emergence of 'a hopeful new science' of ecology in 'the human as well as ... biological fields (Wright 1968, pp. 23-33)'. This could bridge Western civilization's most tragic divide by providing 'a point at which a new spark can perhaps jump across the gap that at present separates the arts and the sciences- to the great detriment of each — and allow a new kind of cooperation and understanding to grow up (Wright 1975, pp. 189-94)'.

John Busst used his organisational acumen and vernacular talents to bombard newspapers like The Australian with pungent articles, arguing that the Reef was destined to become 'a quarry surrounded by an oil-slick' in combining with the personal lobbying of powerful political individuals and institutions (Wright 1977, p. 188). This entailed including harassing his old friend, Prime Minister Harold Holt, into agreeing to test Queensland's spurious claim to sovereignty of the Reef with a case in the High Court. And when Holt disappeared while swimming at Cheviot Beach near Portsea, Victoria in December 1967, he tracked down both the new Liberal Party Prime Minister, John Gorton, and the Opposition Labor Party Leader, Gough Whitlam, whilst they were holidaying on the Reef to win undertakings to fund a Federal marine research station on the Reef and for cross-party support to launch a Royal Commission of Inquiry into oil and gas mining on the Reef. Not content with these concessions, he also joined with sympathetic Queensland Labor Party politicians to lobby trade unions to undertake what proved to be a decisive action of black banning oil company drilling on the Reef. In January 1970, this tactic succeeded in forcing the Japex (Japan Petroleum Exploration Company Limited, Tokyo, Japan) and Ampol Petroleum companies to cancel their proposed drilling at Repulse Bay and John was able to declare to his two colleagues, 'Now at last the breakthrough has come. It has taken two and a half years to find the weapon (Wright 1977, p. 105)'.

The trio's mass of publicity had also prepared Australians for a watershed moment in late January 1969 when a rig started spewing crude oil into the pristine waters of Santa Barbara on California's coast. Australian TV news programs showed infernos of rotting fish, oil-clogged seabirds, and viscous black beaches. Bjelke-Petersen's bleats that it wouldn't happen in Queensland rang hollow a year later when an oil tanker, Ocean Grandeur, struck on a rock at the top of Cape York and poured oil onto the Reef. The Queensland Minister for Mines, Ronald Camm, didn't help much either by arguing that oil, being protein, would nourish fish and other marine organisms (Bowen and Bowen 2002, pp. 319-21). By the early 1970s, polls showed that a majority of Queenslanders now opposed mining of the Great Barrier Reef (Wright 1977, pp. 53-54).

At this point the war was effectively won. The election of the Whitlam Labor government in 1972, the Royal Commission report, and the High Court's decision in favor of Commonwealth sovereignty all paved the way for a political settlement. Both sides of Federal parliament now supported the formation of a multi-use marine park under shared Federal and Queensland management. Dr. Patricia Mather, a zoologist from the University of Queensland, drafted a plan for a Marine Park that accommodated a complex balance of Federal and Queensland State responsibilities and relationship for managing the 
Park, which eventually passed into law in June 1975. Six years later, in October 1981, the Great Barrier Reef gained World Heritage listing 'as the most impressive marine area in the world'.

John Busst didn't live to see the day. Early in 1971 he 'dropped off his twig', as Len put it, and Judith later composed a simple memorial: 'John Busst/Artist and lover of beauty/who fought that man and nature might survive'. Judith herself died in 2000, and Len followed eight years later. Though proud of helping to win the Reef War, the trio always feared that their victory would remain only provisional.

So much has changed in the fifty years since the Reef war of the 1960s that its lessons cannot simply be transposed onto the situation today. Three major differences have to be taken into account by today's environmental humanities scholars and campaigners.

First, unlike the situation in the 1960s, there is now no shortage of Great Barrier Reef scientific research. The Australian Institute of Marine Science (AIMS) in Townsville was founded as direct result of the previous war, and has become a major force in mapping, describing, and understanding the Reef's complex ecosystems, as well as the global and regional oceanographic and atmospheric forces that influence them. It has also generated world famous marine scientists like John 'Charlie' Veron, who has observed, recorded, described and analyzed more Reef corals than anyone else on earth. He and his marine scientist wife, Mary Stafford-Smith, have also produced a comprehensive coral data set of world corals for local and global scientific use.

There are now four substantial specialised marine research stations situated within different sections of the Reef and operated by the Universities of Queensland, Sydney, James Cook, and the Australian Museum. These research stations boast such world leading coral reef scientists as the University of Queensland's Professor Ove Hoegh-Guldberg, James Cook University's Professor Terry Hughes and the University of Sydney's Professor Maria Byrne. Terry Hughes undertook the exhaustive mapping of the 2016 and 2017 bouts of mass coral bleaching from ocean warming, whose repetitions are likely to destroy the Reef altogether in the near future unless the world is able to keep atmospheric warming from greenhouse gas emissions below two degrees Celsius.

Yet we face the strange paradox that the cost, scale and complexity of expertise required to undertake this Reef science has led to campaigns of deliberate and effective obfuscation from vested commercial and political interests who decry professional science for its supposed bias, elitism and corruption. Climate science is attacked in Australia and elsewhere in the Western world as the mere 'opinions' of self-serving professionals rather than as the fruits of a rigorous experimental method perfected and proven over centuries and upheld by ninety percent of today's qualified scientists across the world. Climate skepticism has become a banner of the growing number of populist rightwing political and cultural movements that are sweeping across the western world, including in Australia. And climate scientists in Australia also find few allies among the traditional media. Rightwing 'jocks' on talk-back radio and fleets of journalists within Rupert Murdoch's massive print and TV empire speak as one in their enthusiasm for 'job-creating' fossil fuel industries and in their criticism of climate scientists who are supposedly bent only on self-advancement within leftist, academic or 'green' economies.

At the same time their 'objective' scientific methods exclude today's professional marine and Reef scientists from being able to deploy a range of powerful social, cultural, aesthetic and economic arguments in defense of the Reef. In particular, the kind of supposedly 'emotional' viewpoints advanced in Judith Wright's poetic and philosophical writings, which extolled the indigenous custodianship and the aesthetic, visual and sensual appeal of the Reef are necessarily out of bounds to modern professional marine scientists. Fifty years earlier, when professional boundaries were more porous, Len Webb had no hesitation about incorporating poetics within his ecological repertoire. For access to these dimensions, scientists must rely on collaborations with colleagues in other disciplines and fields, and particularly on those of us who research or practice in the field of the environmental humanities, arts and social sciences. 
At the same time, professional Reef science, though besieged or ignored in Federal and State government circles, continues to throw a long shadow within NGO and academic circles. When I published my recent book, The Reef-A Passionate History. From Captain Cook to Climate Change in various national and international editions between 2013 and 2016, the overwhelming majority of interviewers and reviewers presumed automatically that I must be a marine scientist, and tailored their questions accordingly. This held true even after I explained that I was an historian and attempted to focus their attention also on aesthetic, psychic, cultural and social dimensions of the Reef. Australian scientists cannot be blame for this exclusivity of focus. As someone who takes pride in being an historian of science, my concern rather is that an opportunity for collaborations and enhanced popular support to save the Reef is being lost.

I believe, for example, that Reef scientists need to work with environmental humanities and arts practitioners to reach crucial potential allies in the tourist industry who depend on the beauty, health and wonder of Reef corals and their waters to attract thousands of national and international visitors each year to enjoy the aesthetic and sensual pleasures entailed in recreational swimming, fishing and coral viewing. David Attenborough, the doyen of popular nature film, has described Australia's Great Barrier Reef as the most ravishing organic phenomenon in the world. And if we are to be more utilitarian, Deloitte Access Economics has recently calculated the total economic, social and cultural value of the Reef at $\$ 56$ billion and tourism's asset value within that at $\$ 29$ billion. It also generates 64,000 FTE jobs and brings in $\$ 6.4$ billion to the national economy (Deloitte Access Economics 2017, p. 28). In 1962, the Queensland Tourist Development Board estimated 28,000 tourists had visited the Whitsunday Islands; in 2016 the Great Barrier Reef Marine Park Authority revealed that 2,400,000 people had used authorised tourist operators that year ${ }^{3}$. News of bleaching has, by 2017, however, already produced a rapid and steep decline in the number of visitors (Rebetz 2017).

We might expect under these circumstances that Reef tourist operators would show grave concern at Professor Terry Hughes's recent and exhaustive survey of the extent of bleaching and coral death on the Reef in the recent outbreaks of 2016-2017 (Hughes et al.). Yet far from admitting concern and seeking to work with scientific and humanities allies to preserve the Reef for their own future economic wellbeing, the majority of Reef tourist operators have thrust their heads firmly in the sand. They continue to deny the unique seriousness of climate change-induced coral bleaching, acidification and worsening cyclonic events, with claims that scientists are exaggerating what are simply 'natural' cycles from which Reef corals will inevitably recover. Some corals may do so if they are given the necessary decade or so of respite from further bleaching events, but on present indications this simply won't happen. It is only a matter of time before Reef tourist operators will be forced out of desperation to seek solutions rather than evasions.

That fruitful collaborations between environmental humanities scholars, scientists and Reef tourist operators are possible was brought home to me in 2014 when I was approached for help by a group of local citizens, environmentalists and tourist businesses from the small resort town of Mission Beach, two hours south of Cairns on the Reef's Cassowary Coast. Their town and environs had been savaged by successive disasters. No sooner had the community recovered from the devastation caused by Cyclone Larry in 2006 than, five years later, an even stronger cyclone called Yasi ripped the roofs off local houses, mangled the beaches, waterfronts and fringing reefs, smashed down acres of ancient forest and killed a third of the largest remaining collection of cassowaries in Australia. Faced with this catastrophe, a remarkable coalition of local organisations came together. Having heard about my book on local radio and TV stations, they asked me to join a community reclamation project supported by government and private money, called 'Turning the Tide'. This involved, among other things, building an innovative digital interpretation centre to tell the stories of the Reef.

3 (Bowen and Bowen 2002, pp. 324, 389; Claringbould et al. 1984). Great Barrier Reef Facts, greatbarrierreef.org. Available online: www.greatbarrierreef.org/about-the-reef/great-barrier-reef-facts (accessed on 17 June 2017) 
The still-shattered community had also decided to come together in a collaborative drive to rebuild the Mission Beach locality around the inspirational story of the first war to save the Reef. They asked me to help make that story a rallying point for their traumatised community and a source of economic and cultural renewal for their town's future, as well as a larger symbol for our climate-challenged times. One of our first collaborative actions was to organise a community workshop at Mission Beach funded and attended by members from the multi-disciplinary Sydney Environment Institute of the University of Sydney of which I am Co-Director. Most attendees, however, were Indigenous Aboriginal and European citizens of the town and region. Among them were resort managers, tourist guides, scientists, artists, journalists, lawyers, government officials, and community environmentalists. Proceedings opened with the presentation of a contract from the Queensland Parks and Wildlife Service to give the local community indefinite use of John Busst's original hand-built house and gardens where we were gathered. This, the first cyclone-proof house in Australia, is an eight-bedroom bungalow called 'Ninney Rise'. Backed by towering rain forest and fronted by beaches, reefs and islands, it is also the site from which Wright, Busst and Webb masterminded much of their successful war to save the Reef.

The empty house and two hectares of forest had been bequeathed long ago to the sympathetic Queensland Parks and Wildlife Service, who maintained it and resisted pressures from the State Government to sell it as an 'uneconomic asset'. With their assistance, our local umbrella group of environmental humanities academics, scientists, artists and community activists had obtained Queensland Heritage listing for the building and its environs as the originating site of the 1965-1975 Save the Reef campaign. In future, the house and grounds will function as a Reef and Rainforest environmental research and arts centre for the people of the town and region (Queensland Government 2016). It was a moving example of the power of collaboration for all those redoubtable folk who've endured such unrelievedly tough times.

Yet I don't wish to exaggerate the ease of forging such collaborations. Mission Beach is in some respects a special case because it has already experienced a series of catastrophic climate-exacerbated events that have united normally disparate elements of their community, and because we were, together, able to define and achieve a specific local goal for social renewal-to unite the community around an inspirational historical story. In this respect we resembled the conservationists of the First Reef War, who'd been able to focus their campaign on a single, specific, but still unrealised threat-that the Reef would be opened up to large-scale oil and gas mining. Furthermore, Judith Wright and her colleagues had been able to discover and deploy a decisive tactic to prevent the drilling from taking place by persuading trade unionists to issue black bans against oil company ships and crews. Moreover, a crucial factor in their success was that, despite a number of earlier such test drillings, oil and gas had not actually been found in usable quantities on the Reef ${ }^{4}$. Had the Bjelke-Petersen government been able entice Queenslanders with the definite prospect of a substantial accession of wealth from oil and gas mining, the outcome of the First Reef War might have been much less certain.

By contrast those engaged in the current war to save the Reef are having to combat the stealthy global effects of atmospheric chemical changes that have begun to make their mark since the 1950s, and which by 2016-17 have reached a point where some three quarters of the Reef is suffering the effects of mass coral bleaching which urgently endangers its future survival. Again this represents a crucial difference from the First Reef War. Unlike Wright, Busst and Webb, today's Reef conservationists cannot implement any swift, effective local action to halt this damage: it is global in origin but local in effect. Coral bleaching, acidification, and mega-cyclonic destruction will continue and intensify until international actions are taken to reduce or stabilise global emissions of atmospheric greenhouse gases.

4 (Environmental Justice Australia 2017; Robinson 2017). Mackay Conservation Group. Stop the Boats! Available online: http:/ / www.mackayconservationgroup.org.au/stop_the_boats (accessed on 17 June 2017). 
That these urgent threats to the Reef's future existence are caused by global forces has in turn played into the hands of Australian national and state governments who wish to displace the issue of their responsibility for protecting and preserving the Reef onto other countries and international organisations, bleating that Australia alone is helpless to effect any change. At the same time, trans-Australian or international actions to help the save Reef, such as World Heritage evaluations of Great Barrier Reef health, are represented by right wing populists as interference with Australia's sovereign rights as a nation, even though the destruction of the Reef would also have repercussions for corals and fish over a large part of the Indo-Pacific.

Even some well-disposed humanities, arts and science supporters of the Reef have experienced morale sapping fatalism when confronted with the global enormity of the forces that now threaten the Reef. Australians who live at considerable distances from the Reef or in areas not directly affected by its economic issues can feel especially helpless. Whereas previous popular environmental campaigns, such as preventing the damming of the sublime Franklin River in Tasmania, were susceptible to local and national action, combatting the global scale of many of the present threats to coral reefs appears much more difficult. Federal and Queensland state-sponsored actions, such as fostering the opening of new mega-coalmines at the Galilee Basin adjacent to the Reef, are met with fatalism from some environmentalists on the grounds that the threats these pose to the Reef pale into insignificance compared with those like coral bleaching that arise from global climate change. And it is probably true that stopping the massive Carmichael Coal Mine and its future counterparts would not directly stop the recurrent bouts of coral bleaching that are already on the way to causing the Reef's destruction.

Yet stopping the Adani Carmichael Mine, which was given the formal go-ahead only recently, on 6 June 2017, could prove a counterpart of the kind of tangible and achievable local action-like saving Ellison Reef-that our predecessors in the First Reef War exploited with such portentous success. Stopping the Adani Carmichael Mine would also have the advantage of being an action that links both the local and global threats that face the Reef. The Adani Group is a huge Indian conglomerate headed by the billionaire Gautam Adani, with a disturbingly bad record of environmental violations in Africa and India. It already owns the coal export terminal at Abbot Point adjacent to the Great Barrier Reef, which sends 14,000 container ships of coal through the Reef lagoon each year. Given its prior record, too, we should not be surprised that in April 2017 it discharged coal-laden water eight times above the authorised limit into neighboring wetlands [29] (Environmental Justice Australia 2017; Robinson 2017). Whether it will receive the substantial fine accrued for this violation remains to be seen.

And less than a month later, the same company was approved to open what it intended to be one the largest single coal mines in the world. The Adani Carmichael Mine will encompass five open-cut and five underground pits, as well as massive new rail and port facilities, and has been approved to mine 60 million tonnes of thermal coal per annum for the next 60 years, amounting to a total of 2.3 billion tonnes of coal (Elliot 2016). The Galilee Basin, from which it will draw, and where a further nine mines are projected, is one of the largest unexploited coal-fields in the world and contains an estimated 29 billion tonnes of coal.

In fact, the massive extraction and transporting through the Reef of one of the globe's most polluting fossil fuels has crucial scientific and symbolic implications. First, it will greatly exacerbate the existing stresses on the Reef's corals. Transporting this quantity of coal to India entails a huge influx of shipping traffic through the shallow, fragile, Reef lagoon. From the outset, a minimum of 500 extra coal carrying ships will travel through the Reef each year, greatly intensifying the already severe risks of groundings and oils spills. At peak production this traffic will increase to the colossal figure of 85,000 ships per annum (Australian Marine Conservation Society 2017). This in turn will require substantial dredging of port areas and surrounding seabed, which will churn up silt to contaminate and asphyxiate corals over hundreds of kilometres, including those at two of the adjacent University Marine Research Stations at Heron and One Tree Islands. As well as destroying substantial areas of seagrass meadows essential to the survival of dugong, dredging churns up vimo bacteria responsible for generating the fatal coral disease of white spot. 
The Carmichael Mine (quite apart from the further nine mines projected to operate in the Galilee Basin) will also produce and burn coal on such a scale that it will exert a significant impact on global emissions. This single mine will become the fourth largest supplier-including whole countries-of coal to Asia, and, when burnt, its output of coal will release 120 million tonnes of $\mathrm{CO} 2$ per annum into the atmosphere, an amount greater than the annual emissions of over one hundred individual countries (Australian Marine Conservation Society 2017). As it happens, this figure is an equivalent of Australia's total planned greenhouse gas emissions reductions for the decade of 2020-2030 (Elliot 2016). By Adani's own figures it will emit more than 4.6 billion tonnes of carbon dioxide over its lifetime. This amount would use up one-tenth of the world's total carbon budget, the amount that scientists estimate remains if we are to cease emissions at the level of two degrees Celsius (Krien 2017).

The justification on the part of the Queensland State Government and the supportive Liberal-National Party Federal Government for launching this massive increment to the coal industry at a time when coal-fired facilities are being scaled or closed down in most of the developed world is that this project will bring jobs to Queensland. The figure bandied around by Party enthusiasts such as the Federal Treasurer, while lovingly fondling a chunk of coal in front of the cameras of the House of Representatives, is ten thousand jobs. However, Adani's own chosen 'expert' Jerome Fahrer, a former Reserve Bank economist, testified to the Queensland Land Court that the mine would actually employ around 2400 workers, many of them likely to be individuals moving from less well-paid jobs in agriculture elsewhere in Queensland (Krien 2017).

Moreover, the Australian CEO of Adani Mining, Jeyakumar "JJ" Janakaraj, also confirmed in another context that, as 'a mine of the future', all the operations of the Carmichael Mine from pit to port would be fully automated. Which, then, is most likely - ten thousand jobs or full automation? It cannot be both. Against this, too, we also need to weigh the potential loss of some 64,000 jobs in the tourist industry if the Reef was to perish. But for the short-term opportunists in the state and federal governments, conscious that the seats in Queensland's coal belt could decide their fate at the coming elections, it is important merely that the Carmichael Mine should generate a perception of potential jobs, especially because both governments are also trying to fend off the influence of a rising right wing populist party that is contesting the very same seats (Krien 2017).

How, then, should we in the Australian environmental humanities today seek to adapt the lessons of our First Reef War predecessors to the new challenges of a Second Reef War in an Anthropocene global age? Like Wright, Busst and Webb, we must be prepared to campaign on tangible local and community issues by stopping the operations of corporations and their government allies such as the Adani Carmichael mine. And, like our predecessors, we must be prepared to engage in research and advocacy activities that move beyond our usual academic audiences to chime with the experiences and abilities of a substantial range of ordinary citizens, including Indigenous organisations, church groups, museums and schools. Yet at the same time we cannot afford to limit our research and advocacy to reach only local or even national communities. To combat conglomerates like the Carmichael coal mine, themselves global in organisation and scale, we need to build collaborations with professional global bodies and NGOs committed to common goals. In the case of the Sydney Environment Institute this has entailed working with Future Earth, 350.org, Get Up, the Ocean Conservation Foundation, Greenpeace, and others. We have involved them in our public events and workshops and participated in theirs, and we have worked with them to apply for grants with both research and activist outcomes and to lobby governments and trade unions.

It has been equally important for us to establish global collaborations with like-minded University-based environmental humanities, arts and science scholars and practitioners across the world. For us at the Sydney Environment Institute, this has included working, for example, with dynamic international institutions such as the Germany's Rachel Carson Centre and Sweden's KTH Environmental Humanities Laboratory. But we believe it is also important for environmental humanities groups to organise ourselves formally in order to share knowledge, expertise and political clout of international partners. In a global world we are netted together and our institutions should 
reflect this in order to respond collectively and collaboratively to the pressing issues and challenges to our planet within an Anthropocene age, and which are heralded by climate change. Only thus will we be able to replicate a relevant modern version of the 're-imagining of nature' that Judith Wright believed could encompass 'the arts, affirming the truths of feeling and sciences, affirming the truths of intellect' (Wright 1975, pp. 196-202).

Acknowledgments: The author gratefully acknowledges funding provided by the Australian Research Council in the form of a three year Discovery Grant, DP110101069 'Redeeming the Great Barrier Reef. Science, romanticism and indigenous knowledge in the cultural and ecological history of the reef, c.1850-1950'.

Conflicts of Interest: The author declares no conflict of interest.

\section{References}

Australian Marine Conservation Society. 2017. Adani's Carmichael Coal Mine and Rail Project: Factsheet, April. Available online: https:/ / www.marineconservation.org.au/pages/adani-carmichael-coal-mine-rail-projectfactsheet-html (accessed on 14 June 2017).

Bowen, James, and Margarita Bowen. 2002. The Great Barrier Reef: History, Science, Heritage. Cambridge: Cambridge University Press.

Brady, Veronica. 1998. South of My Days: A Biography of Judith Wright. Sydney: Angus \& Robertson.

Clare, Patricia. 1971. The Struggle for the Great Barrier Reef. London: Collins.

Claringbould, Roy, Jane Deakin, and Pat Foster. 1984. Data Review of Reef Related Tourism 1946-1980; Townsville: Great Barrier Reef Marine Park Authority.

Deloitte Access Economics. 2017. At What Price? The Economic, Social and Icon Value of the Great Barrier Reef. Brisbane: Deloitte Access Economics.

Elliot, Tim. 2016. Decision on coal mine 'defies reason'. The Sydney Morning Herald, April 4. Available online: http://www.smh.com.au/federal-politics/political-news/decision-on-coal-mine-defiesreason-20160403-gnxbc6.html?deviceType=text (accessed on 14 June 2017).

Environmental Justice Australia. 2017. The Adani Brief: What Governments and Financiers Need to Know about the Adani Group's Record Overseas Carlton. VIC: Environmental Justice Australia.

Frazer, Ian. 2003. Conservationism and Farming in Northern Queensland, 1861-1970. Townsville: MA (Research), James Cook University. Available online: https:/ / researchonline.jcu.edu.au/78 / (accessed on 5 July 2017).

Hughes, Terry P., James T. Kerry, Mariana Álvarez-Noriega, Jorge G. Álvarez-Romero, Kristen D. Anderson, Andrew H. Baird, Russell C. Babcock, Maria Beger, David R. Bellwood, Ray Berkelmans, and et al. Global warming and recurrent mass bleaching of corals. Nature 543: 373-77. [CrossRef] [PubMed]

Krien, Anna. 2017. Revealed: Gautam Adani's coal play in the state facing global-warming hell. The Sydney Morning Herald, June 9. Available online: http:/ / www.smh.com.au/good-weekend/adani-how-we-gotconned-by-coal-20170525-gwcw5h.html (accessed on 14 June 2017).

Lines, William J. 2006. Patriots: Defending Australia's Natural Heritage. St Lucia: University of Queensland Press.

Queensland Government. 2016. Ninney Rise and John Busst Memorial. Available online: https:/ /environment. ehp.qld.gov.au/heritage-register/detail/?id=602499 (accessed on 6 July 2017).

Rebetz, Louisa. 2017. Great Barrier Reef 'too Big to Fail' at \$56b, Deloitte Access Economic Report Says. ABC News, June 26. Available online: http:/ / www.abc.net.au/news/2017-06-26/great-barrier-reef-valued-56b-deloitte8649936 (accessed on 28 June 2017).

Robinson, Joshua. 2017. Adani may face fine over sediment released in floodwaters after Cyclone Debbie/Queensland environment department says it is considering action against mining giant with fines of up to $\$ 3.8 \mathrm{~m}$ possible. The Guardian, May 3. Available online: https:/ / www.theguardian.com/environment/ 2017/may /03/adani-may-face-fine-over-sediment-released-in-floodwaters-after-cyclone-debbie (accessed on 6 July 2017).

Roland, Betty. 1984. The Eye of the Beholder. Sydney: Hale \& Iremonger.

Tracey, Geoff. 1988. Len Webb: Pioneer in Ecology of the Rainforests of Australia. Australian Science Magazine 4: 66. Webb, Len. 1967. Notes for an Address to the Students at Kendron Teachers College. Wildlife, June 7.

Wildlife Preservation Society of Queensland. 2000. Heart and Mind: WPSQ Finding Directions in the 60s. Brisbane: Wildlife Preservation Society of Queensland, Historical Papers Monograph 2. 
Wright, Judith. 1975. Because I Was Invited. Melbourne: Oxford University Press.

Wright, Judith. 1977. The Coral Battleground. Melbourne: Thomas Nelson Australia.

Wright, Judith. 1994a. Australia 1970. In Collected Poems, 1942-85. Sydney: Angus \& Robertson.

Wright, Judith. 1968. Conservation as Concept. Quadrant 12: 23-33.

Wright, Judith. 1994b. The Builders. In Collected Poems, 1942-1985. Sydney: Angus \& Robertson.

Wright, Judith. 1996. The Coral Battleground. Sydney: Angus and Robertson. 